УДК 902.7(571.54) + 615.34

ББК $63.5(2 \mathrm{P} 54)+53.59$

DOI 10.31554/2222-9175-2019-35-10-102-109

\author{
С. Б. Миягашева
}

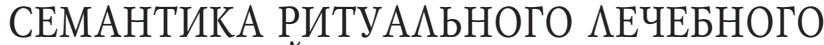 ТАНЦА АНААЙ У МОНГОАЬСКИХ НАРОАОВ
}

Статья посвящена исследованию шаманского лечебного обряда посредством исполнения танцев и песен андай, которые представляют собой уникальный образец магико-медицинских практик монгольских народов. Определено, что андай представлял собой психотерапевтический метод лечения, в котором основные танцевальные движения несли глубокий сакральный смысл - отправление шамана вверх с целью вернуть болезнь на Небо.

Ключевые слова: этномедицина, шаманские целительские обряды, лечение, круговые танцы монгольских народов.

S. B. Miyagasheva

\section{THE SEMANTICS OF ANDAI RITUAL HEALING DANCE OF THE MONGOLIAN PEOPLES}

The article is devoted to the study of the Shamanistic rite of healing by performing dances and songs named Andai, which is a unique example of magical and therapeutic practices of the Mongolian peoples. It is established that Andai was a psychotherapeutic method of treatment, in which the main dance movements carried a deep sacred meaning - sending a shaman upwards, in order to return the disease to heaven.

Keywords: ethnomedicine, shamanistic rites of healing, treatment, dances of the Mongolian peoples.

$\mathrm{Y}$ никальным направлением народной медицины монголов являются ритуалы посредством использования танцев, песен и музыки. Подобные методы исцеления, называвшиеся сэтгэл засах, практиковались в случае психических заболеваний у девушек и женщин и были направлены на балансирование и гармонизацию душевного состояния больной.

В традиционном обществе таким формам заболеваний, как сумасшествие, психические расстройства или депрессия, в основном были подвержены женщины, причем наблюдалось, что болезнь проявляется от тяжелого положения женщин в семье, после вынужденного брака, первой брачной ночи, в начале беременности, после первых родов, после сильного испуга или большой неприятности.

В мифологическом мировоззрении монгольских народов любая болезнь являла собой негативное следствие контакта человека с иным миром, результат нарушения человеком запретов, определяющих взаимодействие земного мира людей с миром божеств и духов [Нанзатов, Содномпилова 2014: 117].

МИЯГАШЕВА Суржана Борисовна - кандидат исторических наук, научный сотрудник Федерального государственного бюджетного учреждения науки «Институт монголоведения, буддологии и тибетологии СО РАН» (Улан-Удэ, Россия). E-mail: surjana.miyagasheva@imbt.ru. 
В представлениях якутов виновниками психологических болезней, называемых эмюрячество и мэнэрячество, считались божества Немирие и Тимир Садалбы Ойуун, последний представлялся наиболее ужасным и проживал на втором (снизу) верхнем небе. Это небо саха называли «сумасшедшим небом» (мэнэриктээх халлаан). Считалось, что от ударов бубна этого божества воют душевнобольные женщины [Григорьева 2012].

У монголов душевные расстройства рассматривались как недуг женщин, одержимых бесами и злыми духами, и психические нарушения назывались адай овчин «болезнь адай» [Гэрлээ 2017: 64]. Интерпретируя со своей точки зрения истоки неведомых болезней, шаманы проводили обряды усмирения обиженных духов и небожителей [Дампилова 2005: 194]. Поэтому пациентов, страдающих подобными заболеваниями, следовало лечить с помощью шаманских методов, посредством ритуального танца андай/адай.

Андай - танец, обладающий целебной силой, который представляет собой уникальный объект нематериального наследия монгольских народов и является образцом танцевально-вокально-поэтического искусства, основанного на ритуале изгнания злых духов [Хишигтогтох 1998: 32]. Андай относится к виду песенного кругового танца, исполняемого шаманом и его помощником с участием душевнобольной пациентки и группы людей. Исполнение подобного танца, сопровождавшегося исполнением импровизированных песен и произнесением заклинаний, представляет собой уникальный ритуал шаманского врачевания.

По мнению монгольских исследователей, этот танец возник еще в первобытную эпоху и был известен всем монгольским племенам и особо широко практиковался у хорчинов Внутренней Монголии [Хурэлшаа и др. 1998: 105]. Известна монгольская народная легенда о его происхождении, которая связывает название ритуального танца с именем девушки Андай, которая была тяжело больна и долгие годы пребывала в депрессии. Ее отец безрезультатно пытался излечить ее, однако все его попытки оказывались напрасными. Однажды, когда они скитались в поисках врачевателей, их повозка сломалась посреди степи, и помощь оказали пастухи, которые своими песнями и танцами смогли развеять грусть и тем самым излечить больную [Саруул 2016: 106].

Женщин и девушек, одержимых психическими заболеваниями, монголы называют андайсан, т. е. «одержимые андай». Для излечения недуга требовалось определить, какой вид танца следует применить: танец орон андай проводился при медицинских показаниях, таких как буйное поведение душевнобольной: если она бегает, издает крики и возгласы и не поддается уговорам. Второй вид ритуальной терапии ад андай был направлен на исцеление тихих больных, которые впадали в глубокую депрессию, вели замкнутый образ жизни, избегали общества и отказывались принимать пищу, тем самым доводя себя до крайнего состояния [Сухбат 2013: 50]. Также выделяли категорию танца ураг андай, который был направлен на исцеление психически нездоровых женщин, чье состояние было вызвано невозможностью завести детей [Гэрлээ 2017: 64].

Обряд лечения проводил шаман со своим помощником. Всю ночь напролет перед совершением ритуального танца шаман камлал в юрте. Под утро душевнобольной девушке распускали волосы, усаживали ее на табурет (обязательно с четырьмя ножками), чтобы обе ноги твердо касались земли. Затем шаман брал в руки музыкальные тарелки цุан и громко гремел над ее головой, призывая духов, ставших причиной недуга. Считалось, что подобные звуки должны напугать зловредных духов [Сухбат 2013: 50]. Подобные методы «устрашения» применялись в магико-медицинской практике якутов, у которых одним из средств 
излечения от сумасшествия, а также порочности и детской смертности считался переход через каменистый ручей с бурным течением. В результате духи болезни, испугавшись бурлящего и шумного водоема, отставали от своих жертв [Бравина 2005: 28].

Далее шаман запевал ритуальную песню, то повышая, то понижая голос, постепенно ритм подхватывала толпа. Во время усиления голоса больная соскакивала с места, и помощник шамана, держащий в руках трость с колокольчиками, отводил ее в круг. Ей вручали платок, и женщина начинала исполнять танец андай вместе с присутствующими [Сухбат 2013: 51].

По одним сведениям, во время исполнения ритуального танца участники держали в руках свечи, ранее применялись факелы [Эрдэнэхорлоо 2014: 82], в чем, несомненно, прослеживается символика очистительной силы огня. В большинстве случаев исполнители андая держали в руках платки разных цветов, которыми усиленно размахивали.

Различается шесть основных композиционных структур исполнения целительного обряда андай: сперва вызывается дух больной, затем проводится изгнание его из тела больной, далее танцевальные движения направлены на призывание фортуны и удачи для больной, следующий этап - вселение духовных сил в больную, после чего следует проверка ее сил, в конце ритм ускоряется и больная начинает двигаться в убыстренном темпе, подтверждая уход болезни.

Признаком восстановления сил и духа больной женщины является выделение обильного пота [Там же: 83]. Для усиления эффекта ей подавали горячий чай, который она должна была пить в больших количествах [Сухбат 2013: 51]. Процесс потоотделения считался признаком того, что болезнь покидает тело. Этот способ лечения имеет рациональную основу, например, у бурят проводились способы лечения путем распаривания веником из трав, веток сосны или ели, смоченным в родниковой воде с заваренными травами по аналогии с банными процедурами, что вызывало обильное потоотделение [Нанзатов, Содномпилова 2014: 123].

Согласно полевым материалам монгольской исследовательницы Түмэннасан Гэрлээ, в старину анай/андай танцевали, держа в руках два края передней полы монгольского дэгэла, размахивая ими, подпрыгивая и вытаптывая, меняя поочередно ноги. Исполняющие ритуал должны были постепенно двигаться по кругу, обязательно по направлению своей левой руки, т. е. против хода солнца. Считалось, что двигаясь в обратную солнцу сторону, изгоняли болезнь, уводя ее от порога входной двери юрты [Гэрлээ 2017: 63].

Символика данного магического шествия против солнца демонстрирует сакральную пространственную ориентацию, связанную с идеей потустороннего мира, и смысл того, что участники ритуального танца уводят болезнь из дома, не давая ей вновь проникнуть за порог. Аналогичное смысловое содержание можно проследить у западных бурят в обряде излечения больного, укушенного бешеной собакой. Больного пропускали через одну прорубь в ледяном озере и вытаскивали через вторую [Жамбалова 2000: 164]. По мнению бурятских этнографов Б. З. Нанзатова и М. М. Содномпиловой, эта традиция несет в себе идею перенесения, оставления зла в ином, потустороннем пространстве [2014: 122].

Архаичные элементы взмахивания нижними подолами монгольского халата в последующем были заменены использованием платочков или хадаков из тканей разных цветов - преимущественного белого, синего или зеленого. Они вручались всем участникам, особенно важным для пациентки было проведение усердных взмахиваний. Усиление подобных взмахов больной рассматривалось как признак ее исцеления и прилива сил [Сухбат 2013: 54]. 
Семантику движения руками в виде взмахивания можно связать со смыслом брызгания и подношения чая, молока божествам. Также вскидывание рук вверх и резкое их опускание могло означать отпугивание злых духов [Гэрлээ 2017: 71].

В описании танцевальных элементов андай указывается, что женщины чередуют платочки в руке и совершают кругообразные движения на уровне груди. На наш взгляд, подобные взмахивания и круговые движения руками олицетворяли притягивание благодати, счастья посредством исцеления. Известно, что у тюрков Южной Сибири колебательные, круговые движения руками означали просьбу «Ниспошли, подай!» и имитацию получения того, что испрашивается, так же как у монгольских народов призывание с произнесением магической формулировки «Ахрай!», повторяемой трижды. Поочередные взмахи руками - одно из архаичных движений, характерных для многих тюркоязычных народов Центральной Азии, в котором заложена идея привлечения к себе благодати, добра, приплода скота [Лукина 2005: 82].

Важно отметить, что махание платком интерпретируется как «навивание» призывание духов, как особый тип камлания, называемый у алтайцев ельби/ильби; они верили, что духи приходят с ветром, вихрем, т. е. движением воздуха. Доходило до того, что люди повторяли подобные движения до изнеможения, чтобы духи остались довольны их ритуальным танцем [Буксикова 2009: 246].

Особое внимание в исследовании семантики лечебно-исцеляющего обряда андай заслуживает структурное устройство места для его исполнения. Для ритуала обустраивали небольшую ровную площадку, посередине которой вертикально сооружали осевой вал от тележки, называемый алтан багана «золотой столб». Этот деревянный столб олицетворял собой лестницу или ворота, по которым небесные божества спускались и прибывали на ритуал призывания андай андай дудах [Эрдэнэхорлоо 2014: 82]. На наш взгляд, «золотой столб» моделировал мировую вертикаль - небесную дорогу, наоборот, ведущую вверх, в мир небожителей. Основанием подобного вывода можно считать версию происхождения названия андай от слова анай (как архаика слова «андай»), что означает «приподнимись» и интерпретируется как «становись здоровым и приподнимись» [Там же].

Учитывая, что психические заболевания рассматривались монгольскими народами как спущенные с неба, возможно, шаман во время танца андай стремился приподняться вверх, чтобы отослать недуг обратно на Небо. Подобные ритуальномифические аспекты прослеживаются у бурят, которые, например, чтобы избавиться от заболевания хорхироо (чума овец), разжигали щепку от дерева, пораженного молнией, и с наступлением сумерек ходили вокруг дома и выкрикивали «Хорхироо дэгдээ!»-Хорхироо, вознесись! [Галданова 1992: 49; Содномпилова 2016: 45]. Или если бешенством заболевал домашний скот, то его следовало немедленно застрелить и тем самым причину болезни ганзу поднять обратно на небо [Хангалов 1958: 416].

Как подчеркивали монгольские информанты, в старинном танце андай преобладали традиции топтания ногами и движения по кругу. Движения ногами представляли ритмичное топтание, сопровождавшееся чередованием ног во время прыжков [Гэрлээ 2017: 63-64]. Кинетический компонент танцев в виде топтания был характерным для ритуальных танцев многих тюрко-монгольских народов. В «Сокровенном сказании» говорится о том, что монголы танцевали, вытаптывая вокруг развесистого дерева до того, что выбивали вокруг него яму по колено за одну ночь [цит. по: Дугаров 1991: 120].

Во-первых, подобные движения могут быть интерпретированы как возбуждение хозяев земли и воды, которое должно было восстановить силы, оказать исцеляющий эффект [Эрдэнэхорлоо 2014: 84]. Во-вторых, топтание несет семантику прокладывания небесной дороги, устремленной вверх. Ярким примером служит воззрение яку- 
тов, у которых ритуальные танцоры битииситы «вытаптывали дорогу» для небесного путешествия своего шамана. Подобный ход является своеобразным символом дороги, устремленной в Верхний мир, по которой можно подняться в сакральную область [Лукина 2005: 83]. В этой связи близкие символические параллели можно провести с бурятским круговым танцем ёхор, который по мнению Д. С. Дугарова в переводе с древнего уйгурского языка означает «вверх»-joqaru, где слова, произносимые в качестве припева выражают понятие «вверх», «вознесись» [1991: 107].

Известно, что аспекты в виде горы, столба, дерева, костра, в данном случае «золотого столба» из тележной оси, определяются как проявление концентрированной точки центра кругового танца и связаны с сакральностью Неба, с его символизмом [Лукина 2014: 55]. Устремление вверх, круговое «вытаптывание» небесной дороги отражает мифологические представления монгольских народов, связанные с идеей путешествий на Небо.

Подтверждением подобным выводам являются этнографические материалы монгольского исследователя Б. Шулуу, который связывает происхождение танца андай с культом почитания белого коршуна цагаан илээ. Он указывает, что проведение ритуала сопровождается подражающими движениями птицы и сакральный характер танца определяется стремлением позаимствовать у коршуна способность полета к Небесам [Саруул 2016: 105]. В мировоззрении монгольских народов белый коршун имел возможность пересекать все три мира. Коршун считался птицей, способной изгонять злых духов и лечить болезни.

Для проведения исцеляющего ритуала илээ в доме больного шаман проводил обряд поклонения молочной водкой белому коршуну. Он вызывал дух птицы и после вселения в его тело начинал бить больного, а также окружающие предметы черным платком, с тем чтобы изгнать духа болезни [Там же]. В данном случае использование черного платка является имитированием поведения и движения птиц и может быть определено в качестве элемента архаического подражательного танца.

Возможно, стремление вознестись в небеса кроется в сакральном назначении танца - андай имитировал полет коршуна и был направлен на шаманское приподнятие вверх к небесам с целью вернуть болезнь обратно.

Андай исполняли в любое время года, даже в зимнее время устраивали внутри жилища, в связи с этим различали два вида исполнения ритуального обряда - бага aдай (малый адай) и их адай (большой адай). Их адай проводится коллективно, на специально подготовленной площадке, а малый бага адай - в юрте, в случае, если больная в тяжелом состоянии и не может выйти наружу [Гэрлээ 2017: 65]. Исполнение танца могло длиться от 7 дней до 21. В большинстве случаев существовала традиция спрашивать срок исполнения обрядового танца у самой душевнобольной женщины [Эрдэнэхорлоо 2014: 82].

В старину танцевали под аккомпанемент шаманского бубна и трости с колокольчиками, затем стали использовать четырехструнный хуyр, а в последующем другие музыкальные инструменты - шанз, лимбэ, морин хуур. Считалось, что магическая музыка андай является профилактикой не только психоневротического состояния. Монголы исполняли танец андай и пели песни в качестве исцеляющего средства сердечно-сосудистых заболеваний. В последующем спектр показаний для проведения андай стал определяться следующими болезнями: его рекомендовали при растяжении мышц, ослаблении суставов, заболеваниях опорно-двигательного аппарата. Запрещалось участие в андай беременным женщинам и тяжелобольным людям [Сухбат 2013: 55].

Кульминационным магическим действом танца андай является обряд изгнания болезни андай гаргах, проводимый в последний день шаманского ритуального исцеления. Для этого участники танца изготавливали из белой бумаги макет жилища или 
дворца. Они нараспев хвалят и возносят словами этот дом, шаман усиленно трясет тростью с колокольчиками, произносит слова призываний и обращений, уговаривая и зазывая духов болезни поселиться в нем и освободить тело больной [Сухбат 2013: 54].

Подобный ритуал можно сравнить с психотерапевтическим способом лечения у бурят с помощью обряда долё путем выкупа души больного. Для его проведения черный шаман обращался к духам болезней и взамен на душу больного предлагал им жертвы долё в виде коз, овец, крупного рогатого скота или лошадей, в крайнем случае предлагал душу другого человека [Михайлов 1987: 168]. В последующем для ритуала долё стали применять фигурки животных или человека, слепленные из теста, которые сжигались в конце обряда. После «вселения» духов недуга в новое жилище обряд андай считался завершенным. В последующем за бывшей больной предполагался хороший уход, в тишине и полном покое [Сухбат 2013: 55].

Таким образом, основным мотивом исцеления посредством ритуала андай являлся психотерапевтический метод лечения посредством физических движений, среди которых отметим топтание ногами как ассоциацию путешествия вверх, взмахивание платочками, распев мелодии, исполнение песен и произнесение слов камлания, обращений к духам болезни покинуть тело больной.

Подобный шаманский ритуал излечения в последующем был перенят буддизмом. Со второй половины XVI в. в результате трансформации шаманизма под влиянием буддизма среди хорчинов Внутренней Монголии широко практиковался ритуал лечения с помощью андай, проводимый так называемыми лайчинами - людьми, проводящими ритуалы по изгнанию злых духов, практиковавшими шаманские и ламаистские доктрины [Саруул 2016: 106].

В целом танец андай, так же как якутский осуохай или бурятский ёхор, подразумевал собой синкретизм обрядового магического действа, игры (в обрядовом контексте), танца и пения, семантика которого включала широкий диапазон ритуалов и базировалась на обрядовой функции, шаманских обрядах жертвоприношения и умилостивления божеств, призывания или приманивания счастья [Дашиева 2009: 31], что объясняется генетической связью этих танцев с центральноазиатской религиозной системой.

Однако наиболее близкие аналогии танец андай находит с найгурами у предбайкальских бурят. Найгуры представляли собой религиозные истерии и групповые камлания шаманистов для поиска и обнародования (признания) культа нового духапокровителя заяна [Манжигеев 1978: 27]. Найгуры стихийно зарождались в улусах бурят, особенно в связи с различными эпидемиями, или посвящались девушкам и женщинам, умершим насильственной смертью.

В мировоззрении западных бурят мотив преждевременной смерти в результате жестокого обращения мужей с женами приводил к причислению таких женщин к сонму святых заянок, как безвинно пострадавших, которые пытались мстить за свою насильственную смерть [Дампилова 2005: 180]. В честь них устраивали найгурские хождения по селам и деревням, во время которого найгуршины пребывали в состоянии эмоционального возбуждения, исполняли импровизированные заянские песнопения, сопровождая их ритмическими телодвижениями, поклонами, покачиванием [Манжигеев 1978: 27]. Подобные обряды сопровождались громкими песнопениями под звуки шаманского бубна и колокольчика, обмахиванием пестрыми платками, кнутами [Дампилова 2005: 179], т. е. с применением атрибутов, использовавшихся во время исполнения танца андай.

Отметим, что в обоих случаях подобные танцевальные ритуалы носили не рациональный, а магический характер и представляли собой уникальный образец ритуальных целительных обрядов народов Центральной Азии. 
Исследование выполнено при поддержке гранта Российского научного фонда (проект № 19-18-00031).

\section{\итература}

Бравина Р. И. Концепция жизни и смерти в культуре этноса: на материале традиций саха. - Новосибирск: Наука, 2005.

Буксикова О. Б. Танцевально-пластическая культура в артефактах Восточной Сибири и ее метаморфозы в народном танце / О. Б. Буксикова // Известия Российского государственного педагогического университета им. А. И. Герцена. - 2009. - № 106. - С. 241-249.

Галданова Г. Р. Закаменские буряты: ист.-этногр. очерки (вторая половина XIX - первая половина ХХ в.) / Г. Р. Галданова. - Новосибирск: Наука, 1992. - 172 с.

Григорьева А. Народная медицина саха [Электронный ресурс] / А. Григорьева. - Якутск: Бичик, 2012. - 160 с. - Режим доступа: https://www.readanywhere.ru/grigoreva-aleksandramixajlovna/books/narodnaya-medicina-saxa/1022998/Trial (дата обращения: 13.06.19).

Гэрлээ T. Исследование танца андай / Т. Гэрлээ // Традиции и инновации в хореографическом образовании: мат-лы Всерос. науч.-практ. конф. с междунар. участием, посвящ. 45-летию кафедры хореографии. - Улан-Удэ, 2017. - С. 63-71.

Дампилова Л. С. Шаманские песнопения бурят: символика и поэтика / Л. С. Дампилова. - Улан-Удэ: Изд-во БНЦ СО РАН, 2005. - 248 с.

Дашиева Л. Д. Бурятский круговой танец ёхор: историко-этнографический, ладовый, ритмический аспекты / Л. Д. Дашиева. - Улан-Удэ: БНЦ СО РАН, 2009. - 210 с.

Дугаров Д. С. Исторические корни белого шаманства (на материале обрядового фольклора бурят) / Д. С. Дугаров. - М.: Наука, 1991. - 300 с.

Жамбалова С. Г. Профанный и сакральный миры ольхонских бурят (XIX-XX вв.) / С. Г. Жамбалова. - Новосибирск: Наука, 2000. - 395 с.

Лукина А. Г. Ритуальный танец битии в контексте обрядового действа / А. Г. Лукина // Наука и образование. - 2005. - № 3(39). - С. 80-84.

Лукина А. Г. Якутский круговой танец осуохай в контексте мировоззренческих представлений / А. Г. Лукина // Круговой танец: Природа - Человек - Космос. - Якутск, 2014. C. 52-63.

Манжигеев И. А. Бурятские шаманистические и дошаманистические термины. Опыт атеистической интерпретации / И. А. Манжигеев. - М.: Наука, 1978. - 127 с.

Михайлов Т. М. Бурятский шаманизм. История. Структура. Социальные функции / Т. М. Михайлов. - Новосибирск: Наука, 1987. - 287 с.

Нанзатов Б. 3. Природа заболеваний в традиционных представлениях монгольских народов и практики народно-бытовой медицины / Б. З. Нанзатов, М. М. Содномпилова // Вестник Бурятского научного центра СО РАН. - 2014. - № 3(15). - С. 116-126.

Саруул. Хорчинский традиционный танец андай / Саруул // Вестник Бурятского научного центра СО РАН. - 2016. - № 2(22). - С. 104-107.

Содномпилова М. М. Эпидемические заболевания в жизни монгольских народов / М. М. Содномпилова // Вестник Бурятского научного центра СО РАН. - 2016. - № 3(23). C. 41-52.

Сухбат Ш. Хөх ухны дом засал, бөөгийн засал, эмчилгээ / Ш. Сухбат. - Улаанбаатар, 2013. $-242 \mathrm{x}$.

Хангалов М. Н. Собрание сочинений. Т. 1 / М. Н. Хангалов. - Улан-Удэ: Бурят. кн. издво, 1958. -552 с.

Хурэлшаа. Хорчин бөө мөргөлийн судлал / Хурэлшаа, Бай Цуйьин, Начин, Баянцугла. Үндэстний хэвлэлийн хороо, 1998.

Хишигтогтох Ц. Андайн үүсэл, тууний бүжиг хүгжим шүлгийн нийлмэл урлагийн хэлбэрт холбогдох нь / Ц. Хишигтогтох // Монголын эртний утга зохиолын шинэ өгүүлэл. Өвөр Монголын хэблэлийн хороо, 1998.

Эрдэнэхорлоо Ж. Традиция монгольского кругового танца / Ж. Эрдэнэхорлоо // Круговой танец: Природа - Человек - Космос. - Якутск, 2014. - С. 79-84. 


\section{References}

Bravina R. I. Koncepciya zhizni i smerti v kul'ture etnosa na materiale tradicij saha. - Novosibirsk: Nauka, 2005.

Buksikova O. B. Tanceval'no-plasticheskaya kul'tura v artefaktah Vostochnoj Sibiri i ee metamorfozy v narodnom tance / O. B. Buksikova // Izvestiya Rossijskogo gosudarstvennogo pedagogicheskogo universiteta im. A. I. Gercena. - 2009. - № 106. - S. 241-249.

Galdanova G. R. Zakamenskie buryaty: ist.-etnogr. ocherki (vtoraya polovina XIX - pervaya polovina XX v.) / G. R. Galdanova. - Novosibirsk: Nauka, 1992. - $172 \mathrm{~s}$.

Grigor'eva A. Narodnaya medicina saha [Elektronnyj resurs] / A. Grigor'eva. - Yakutsk: Bichik, 2012. - 160 s. - Rezhim dostupa: https://www.readanywhere.ru/grigoreva-aleksandra-mixajlovna/books/narodnaya-medicina-saxa/1022998/Trial (data obrashcheniya: 13.06.19).

Gerlee T. Issledovanie tanca andaj / T. Gerlee // Tradicii i innovacii v horeograficheskom obrazovanii: mat-ly Vseros. nauch.-prakt. konf. s mezhdunar. uchastiem, posvyashch. 45-letiyu kafedry horeografii. - Ulan-Ude, 2017. - S. 63-71.

Dampilova L. S. Shamanskie pesnopeniya buryat: simvolika i poetika / L. S. Dampilova. Ulan-Ude: Izd-vo BNC SO RAN, 2005. - 248 s.

Dashieva L. D. Buryatskij krugovoj tanec yohor: istoriko-etnograficheskij, ladovyj, ritmicheskij aspekty / L. D. Dashieva. - Ulan-Ude: BNC SO RAN, 2009. - 210 s.

Dugarov D. S. Istoricheskie korni belogo shamanstva (na materiale obryadovogo fol'klora buryat) / D. S. Dugarov. - M.: Nauka, 1991. - 300 s.

Zhambalova S. G. Profannyj i sakral'nyj miry ol'honskih buryat (XIX-XX vv.) / S. G. Zhambalova. - Novosibirsk: Nauka, 2000. - 395 s.

Lukina A. G. Ritual'nyj tanec bitii v kontekste obryadovogo dejstva / A. G. Lukina // Nauka i obrazovanie. - 2005. - № 3 (39). - S. 80-84.

Lukina A. G. Yakutskij krugovoj tanec osuohaj v kontekste mirovozzrencheskih predstavlenij / A. G. Lukina // Krugovoj tanec: Priroda - Chelovek - Kosmos. - Yakutsk, 2014. - S. 52-63.

Manzhigeev I. A. Buryatskie shamanisticheskie i doshamanisticheskie terminy. Opyt ateisticheskoj interpretacii / I. A. Manzhigeev. - M.: Nauka, 1978. - 127 s.

Mihajlov T. M. Buryatskij shamanizm. Istoriya. Struktura. Social'nye funkcii / T. M. Mihajlov. - Novosibirsk: Nauka, 1987. - 287 s.

Nanzatov B. Z. Priroda zabolevanij v tradicionnyh predstavleniyah mongol'skih narodov i praktiki narodno-bytovoj mediciny / B. Z. Nanzatov, M. M. Sodnompilova // Vestnik Buryatskogo nauchnogo centra SO RAN. - 2014. - № 3 (15). - S. 116-126.

Saruul. Horchinskij tradicionnyj tanec andaj / Saruul // Vestnik Buryatskogo nauchnogo centra SO RAN. - 2016. - № 2(22). - S. 104-107.

Sodnompilova M. M. Epidemicheskie zabolevaniya v zhizni mongol'skih narodov / M. M. Sodnompilova // Vestnik Buryatskogo nauchnogo centra SO RAN. - 2016. - № 3(23). - S. 41-52.

Сухбат Ш. Хөх ухны дом засал, бөөгийн засал, эмчилгээ / Ш. Сухбат. - Улаанбаатар, 2013. $-242 \mathrm{x}$.

Hangalov M. N. Sobranie sochinenij. T. 1 / M. N. Hangalov. - Ulan-Ude: Buryat. kn. izd-vo, 1958. $-552 \mathrm{~s}$.

Хурэлшаа. Хорчин бөө мөргөлийн судлал / Хурэлшаа, Бай Цуйьин, Начин, Баянцугла. Үндэстний хэвлэлийн хороо, 1998.

Хишигтогтох Ц. Андайн үүсэл, тууний бүжиг хүгжим шүлгийн нийлмэл урлагийн хэлбэрт холбогдох нь / Ц. Хишигтогтох // Монголын эртний утга зохиолын шинэ өгүүлэл. Өвөр Монголын хэблэлийн хороо, 1998.

Erdenekhorloo Zh. Tradiciya mongol'skogo krugovogo tanca/Zh. Erdenekhorloo // Krugovoj tanec: Priroda - Chelovek - Kosmos. - Yakutsk, 2014. - S. 79-84. 